\title{
The Prevalence of False Allegations of Rape in the United States from 2006-2010
}

Andre W. E. A. De Zutter ${ }^{1,2^{\star}}$, Robert Horselenberg ${ }^{2}$ and Peter J van Koppen ${ }^{1}$

${ }^{1}$ Department of Criminal Law and Criminology, VU University Amsterdam, Netherlands

${ }^{2}$ Department of Criminal Law and Criminology, Maastricht University, Netherlands

"Corresponding author: Andre W. E. A. De Zutter, Department of Criminal Law and Criminology, Faculty of Law, VU University Amsterdam, De Boelelaan 1105, 1081 HV Amsterdam, Netherlands, Tel: 0031654951216; E-mail: a.w.e.dezutter@vu.nl

Received date: February 10, 2017; Accepted date: March 15, 2017; Published date: March 20, 2017

Copyright: (c) 2017 De Zutter AWEA, et al. This is an open-access article distributed under the terms of the Creative Commons Attribution License, which permits unrestricted use, distribution, and reproduction in any medium, provided the original author and source are credited.

\begin{abstract}
False allegations constitute a public problem since they result in a waste of time spent by the police and justice departments, and may cause public and individual harm. A prevalence study was conducted to obtain recent and valid figures of the prevalence of unfounded allegations of rape and unfounded allegations of other crimes. The most recent published prevalence figures on false allegations in the U. S. are from 1992. At the time cases were cleared by labeling cases as unfounded crimes. Since then guidelines to label a case as unfounded have become more strict. To test whether the new guidelines issued by the Uniform Crime Reporting (UCR) Program of the Federal Bureau of Investigations (FBI) were followed we compared the current results with the prevalence rate of false and baseless allegations of rape before the guidelines were issued. Over a five-year period, from 2006 until 2010, the prevalence of false and baseless allegations of offences in the U. S. was studied. We found that the new guidelines were followed by law enforcement agencies. We performed a Kruskal Wallis Non Parametric Chi Square test of Goodness-of-fit on the proportions of false and baseless allegations to test whether the proportions were equal for all offence types. False and baseless allegations were not equally distributed across offence types $X^{2}(7$, $\mathrm{N}=8000)=120.19, p<0.0001$. The post hoc test revealed significant differences with the group average of $1.16 \%$ for false and baseless allegations of murder $X^{2}(1, N=1000)=39.94, p<0.0001$, false and baseless allegations of rape $X^{2}$ $(1, N=1000)=171.94, p<0.0001$, and false and baseless allegations of robbery $X^{2}(1, N=1000)=187.78, p<0.0001$. Approximately $5 \%$ of the allegations of rape were deemed false or baseless. That was at least five times higher than for most other offence types.
\end{abstract}

Keywords: Crime; Allegations; True; False; Rape; FBI; Unfounded

\section{The Prevalence of False Allegations}

Not all allegations of crimes are truthful. Sometimes people who present themselves as victims make false claims of victimization. A false allegation is defined as an allegation of a crime filed by a complainant to the police while in reality no crime has occurred, the complainant is not a victim of the alleged crime.

False allegations constitute a public problem since they result in a waste of time spent by the police and justice departments, and may cause public and individual harm. It seems imperative to know the prevalence of a problem in order to contain or solve the problem. In other words, the prevalence is a prerequisite to outline an effective policy to eliminate false allegations as much as possible.

False allegations of rape, in contrast with other offence types, received a lot of attention from scholars. There is a heated debate about false allegations of rape with extreme claims at both ends. Brownmiller [1] claims that almost all allegations are true, and Kanin [2] that all allegations are false.

Whereas Greer [3] claims Brownmiller's false rape figure is untrue since this figure was not based on scientific research, Kanin's figure has not been replicated either, and will probably be a consequence of methodological flaws.

\section{The Prevalence of False Allegations of Rape}

An overview of studies on the prevalence of false allegations of rape in the U.S. and other countries was published by Rumney [4]. He reviewed a total of 20 studies, and reported the prevalence rates the researchers found in the study. He did not include the $2 \%$ figure reported by Brownmiller [1], but included another prevalence rate of $2 \%$ that was reported by Katz and Mazur [5]. It was based on the research conducted by Hursch and Selkin [6] who classified an allegation as false when the complainant admitted that the allegation was indeed false. The researchers who conducted the other studies reported prevalence rates varying from 3 to $90 \%$.

The large variation of prevalence rates reported by Rumney [4] is due to methodological differences. Many studies employed unreliable and invalid methods of data gathering (e.g., using vague definitions, using unreliable and invalid criteria, relying on police classification [7]. Rumney [4] concluded that because of methodological problems it is impossible to use the studies that were reviewed to estimate the true prevalence rate of false allegations of rape. The controversy concerning the prevalence of false allegations persists [8-10].

\section{Outdated Figures}

Recent figures on the prevalence of false allegations of rape are absent. Four studies on the prevalence of false allegations in general were published in the $21^{\text {st }}$ century [11-14]. The joint inspection of Her Majesty's Inspectorate of Constabulary (HMIC) and her Majesty's 
Crown Prosecution Service Inspectorate (HMCPSI) into the investigation and prosecution of rape offences in England and Wales deemed that 164 allegations out of 1,379 were false allegations of rape $(11.8 \%$; [11]). In the study conducted by Lea et al. [14] no clear statistics were reported. But, based on the information provided by the researchers we calculated that 38 out of $379(10 \%)$ allegations of rape were considered to be false. Nineteen (5\%) allegations were considered to be false because the complainants had retracted the allegation, and had admitted that the allegation was false. The other 19 (5\%) allegations were considered to be false because police officers said that the allegations were false. Jordan [12] reported that 68 out of 164 $(41.5 \%)$ allegations were false. Thirteen allegations were considered to be false because the complainants had retracted the allegation, and had admitted that the allegation was false. Fifty-five allegations were false according to police officers; 26 allegations were believed to be false by police officers, and were retracted by the complainants, and the remaining 29 were classified as false allegations based on the police investigation. Kelly et al. [13] found that 216 out of 2643 (8\%) allegations of rape were classified as false allegations. In 120 out of the 216 false allegations an explanation of the reason for classifying the allegation as false was given. In 53 cases according to the police officers the complainants had retracted the allegation, and had admitted that the allegation was false. In 28 cases the complainant had retracted the allegation. In three cases the complainant refused to cooperate with the police. The remaining 56 allegations were classified as false based on the police investigation.

More recent figures on the prevalence of false allegations of rape are lacking, because although the studies were published in the $21^{\text {st }}$ century, the data gathering process was conducted in the $20^{\text {th }}$ century for three out of four studies [11-14] gathered the data more than ten years ago. The most recent data in the study were from 2002. As far as figures go for the U.S., they refer to data reported in 1992 [15]. Dershowitz [15] reported based on figures provided by the Uniform Crime Reporting (UCR) Program of the Federal Bureau of Investigations (FBI) that in the U.S. $8 \%$ of all allegations of rape were unfounded. Since then guidelines of law enforcement agencies in the U.S. to collect and label data have changed. Due to the changes it is to be expected that recent figures are more valid.

\section{The Unfound Category and the New Policy}

False allegations are categorized by law enforcement agencies in the U.S. as unfounded crimes. In 1992 the unfounded crime category comprised more than false allegations alone, and was sometimes used to clear out crimes [16]. If an offence was classified as unfounded it was not counted as an unsolved crime. Since then the guidelines have changed, and are more strict to avoid that true allegations are misclassified as false.

The new guidelines of the Uniform Crime Reporting (UCR) Program of the Federal Bureau of Investigations (FBI) and the International Association of Chiefs of Police (IACP) to unfound allegations of rape are the same, it is, therefore, redundant to cite them both. The UCR guidelines of the FBI state that a law enforcement agency in the U.S. has to establish through investigation that the reported rape did not occur in order to deem an allegation unfounded $[17,18]$.

Uncertainty of how strict and to what extent the new guidelines are followed by law enforcement agencies will never be fully dispelled. The new guidelines, however, can be expected to have led to more valid figures on the prevalence of false allegations of rape. A study by Spohn et al. [19] does not seem to reject the validity of this hypothesis.

Spohn et al. [19] studied a random sample of 401 allegations of sexual assaults at the Los Angeles Police Department (LAPD) that were filed in 2008, to test whether the guidelines of the FBI and IACP to unfound cases are followed by police officers. The researchers concluded that in $2.4 \%$ of all allegations of sexual assault that were classified by LAPD officers as unfounded evidence existed that a crime did occur. In $9.9 \%$ of unfounded allegations Spohn et al. [19] concluded that there was evidence that complainants lacked interest to pursue the case or were motivated by fear or pressure to stop pursuing the case. Thus, a total of $12.3 \%$ of all allegations were deemed to be misclassified by the LAPD. Spohn et al. [19] wrote "One conclusion that can be drawn from these data is that the LAPD is clearing sexual assault cases as unfounded appropriately most, but not all, of the time" (p: 173).

The unfounded category, however, is a broader category than false allegations alone, it also consists of baseless cases. A baseless case is a case that does not meet the legal criteria for the crime [9]. Thus, also if the classification process is flawless then some proportion of cases would still not be false allegations in the sense that the complainant deliberately tried to mislead everyone.

In the study by Spohn et al. [19] five cases, $6.2 \%$ of all unfounded cases, that were correctly classified as unfounded by the LAPD were labeled by the rearchers as baseless allegations. If the LAPD, which is one of the largest police departments in the U.S., is representative for law enforcement agencies in the U.S. then recent figures from the UCR could help to resolve the heated debate on prevalence of false and baseless rape allegations in the U.S.

We compare the rate of false and baseless rape allegations to false and baseless allegations for any number of other crimes to test the hypothesis that false and baseless allegations of rape are more prevalent than false and baseless allegations of crimes in general.

\section{Method}

We received the raw crime statistics of the U.S. from the UCR of the FBI. That included the master files from 1960 until 2010. The files contained raw data from every law enforcement agency in the U.S. [20]. We extracted the data from the files, and imported the data in SPSS. Our sample consisted of a recent five-year period, from 2006-2010. We chose a recent time period to make sure we obtained figures of a time period when the new guidelines applied, and were implemented for some time. A five year period was chosen to increase the reliability of the figures.

\section{Procedure}

We divided the number of crimes into different categories. The category of unfounded cases (i.e., false and baseless allegations), of actual cases (i.e., probable true allegations), and of cases cleared by arrest. We chose the most typical crimes for comparison: Rape Total, Rape by force, Murder, Manslaughter, Robbery, Assault, Burglary, Theft, and Larceny (Table 1). The Total crime category, however, includes all types of crimes within this time frame. We also compared the unfounded category with the actual offences category (Table 2). 
Citation: De Zutter AWEA, Horselenberg R, van Koppen PJ (2017) The Prevalence of False Allegations of Rape in the United States from 2006-2010. J Foren Psy 2: 119. doi:10.4172/2475-319X.1000119

Page 3 of 5

\begin{tabular}{|c|c|c|c|c|c|c|c|c|c|c|c|c|c|c|c|}
\hline \multirow[t]{3}{*}{ Year } & \multicolumn{15}{|c|}{ Offences } \\
\hline & \multicolumn{3}{|c|}{2006} & \multicolumn{3}{|c|}{2007} & \multicolumn{3}{|c|}{2008} & \multicolumn{3}{|c|}{2009} & \multicolumn{3}{|c|}{2010} \\
\hline & $\begin{array}{l}\text { Un- } \\
\text { found } \\
\text { ed }\end{array}$ & Actual & $\begin{array}{l}\text { Cleared } \\
\text { by arrest }\end{array}$ & $\begin{array}{l}\text { Un- } \\
\text { found } \\
\text { ed }\end{array}$ & Actual & $\begin{array}{l}\text { Cleared } \\
\text { by arrest }\end{array}$ & $\begin{array}{l}\text { Un- } \\
\text { found } \\
\text { ed }\end{array}$ & Actual & $\begin{array}{l}\text { Cleared } \\
\text { by arrest }\end{array}$ & $\begin{array}{l}\text { Un- } \\
\text { found } \\
\text { ed }\end{array}$ & Actual & $\begin{array}{l}\text { Cleared } \\
\text { by arrest }\end{array}$ & $\begin{array}{l}\text { Un- } \\
\text { found } \\
\text { ed }\end{array}$ & Actual & $\begin{array}{l}\text { Cleared } \\
\text { by arrest }\end{array}$ \\
\hline Murder & 546 & 16,822 & 9,186 & 531 & 16,764 & 9,250 & 538 & 16,056 & 9,381 & 550 & 15,166 & 8,949 & 543 & 14,577 & 8,418 \\
\hline $\begin{array}{l}\text { Manslau } \\
\text { ghter }\end{array}$ & 6 & 621 & 480 & 27 & 818 & 523 & 9 & 728 & 502 & 6 & 657 & 478 & 3 & 618 & 438 \\
\hline $\begin{array}{l}\text { Rape } \\
\text { Total }\end{array}$ & 4,959 & 85,455 & 33,674 & 5,108 & 83,080 & 32,096 & 5,102 & 82,256 & 32,732 & 4,915 & 82,838 & 32,650 & 4,400 & 83,218 & 31,213 \\
\hline $\begin{array}{l}\text { Rape by } \\
\text { Force }\end{array}$ & 4,412 & 76,060 & 29,379 & 4,555 & 74,832 & 28,108 & 4,617 & 74,555 & 29,054 & 4,462 & 75,302 & 29,214 & 4,020 & 73,129 & 27,952 \\
\hline Robbery & 374 & 6,662 & 2,668 & 412 & 6,369 & 2,613 & 386 & 6,057 & 2,397 & 345 & 5,521 & 2,274 & 328 & 5,471 & 2,131 \\
\hline Assault & 3,951 & $\begin{array}{l}4,39,5 \\
71\end{array}$ & 98,048 & 4,095 & $\begin{array}{l}4,38,7 \\
77\end{array}$ & $1,00,902$ & 4,275 & $\begin{array}{l}4,36,3 \\
63\end{array}$ & $1,04,232$ & 4,162 & $\begin{array}{l}4,03,8 \\
74\end{array}$ & $1,00,083$ & 3,411 & $\begin{array}{l}3,64,7 \\
99\end{array}$ & 90,455 \\
\hline Burglary & 32,749 & $\begin{array}{l}36,91 \\
442\end{array}$ & $19,61,253$ & 33,888 & $\begin{array}{l}37,41 \\
293\end{array}$ & $19,53,323$ & 33,388 & $\begin{array}{l}36,99 \\
013\end{array}$ & $19,65,809$ & 33,960 & $\begin{array}{l}36,75 \\
740\end{array}$ & $19,63,402$ & 34,267 & $\begin{array}{l}36,36 \\
040\end{array}$ & $19,44,704$ \\
\hline Theft & 36,968 & $\begin{array}{l}21,09 \\
095\end{array}$ & $2,49,573$ & 35,835 & $\begin{array}{l}21,09 \\
687\end{array}$ & $2,45,535$ & 33,464 & $\begin{array}{l}21,57 \\
749\end{array}$ & $2,56,282$ & 28,016 & $\begin{array}{l}21,45 \\
360\end{array}$ & $2,48,114$ & 26,296 & $\begin{array}{l}21,20 \\
509\end{array}$ & $2,44,596$ \\
\hline Larceny & 48,299 & $\begin{array}{l}61,77 \\
523\end{array}$ & $10,26,560$ & 48,515 & $\begin{array}{l}61,59, \\
542\end{array}$ & $10,89,339$ & 47,638 & $\begin{array}{l}61,80 \\
124\end{array}$ & $11,81,906$ & 47,888 & $\begin{array}{l}59,98 \\
729\end{array}$ & $12,11,145$ & 45,325 & $\begin{array}{l}58,99 \\
028\end{array}$ & $11,73,491$ \\
\hline $\begin{array}{l}\text { Crimes } \\
\text { Total }\end{array}$ & $\begin{array}{l}1,55,0 \\
60\end{array}$ & $\begin{array}{l}1,27,1 \\
4,775\end{array}$ & $34,99,118$ & $\begin{array}{l}1,55,3 \\
23\end{array}$ & $\begin{array}{l}1,26,9 \\
9,798\end{array}$ & $35,38,888$ & $\begin{array}{l}1,50,2 \\
34\end{array}$ & $\begin{array}{l}1,26,6 \\
6,246\end{array}$ & $36,39,519$ & $\begin{array}{l}1,41,4 \\
05\end{array}$ & $\begin{array}{l}1,22,4 \\
8,083\end{array}$ & $36,33,991$ & $\begin{array}{l}1,33,6 \\
77\end{array}$ & $\begin{array}{l}1,21,3 \\
9,746\end{array}$ & $35,62,974$ \\
\hline
\end{tabular}

Note: The figures are the absolute number of offences per category for the U.S. as a whole per year.

Table 1: Crime statistics of the Uniform Crime Reporting program of the Federal Bureau of Investigations.

\begin{tabular}{|c|c|c|c|c|c|c|}
\hline Year & 2006 & 2007 & 2008 & 2009 & 2010 & All years \\
\hline Crimes total & 1.2 & 1.21 & 1.17 & 1.14 & 1.09 & 1.16 \\
\hline Murder & 3.14 & 3.07 & 3.24 & 3.5 & 3.59 & 3.3 \\
\hline Manslaughter & 0.96 & 3.2 & 1.22 & 0.9 & 0.48 & 1.35 \\
\hline Robbery & 5.32 & 6.08 & 5.99 & 5.88 & 5.66 & 5.78 \\
\hline Assault & 0.89 & 0.92 & 0.97 & 1.02 & 0.93 & 0.95 \\
\hline Burglary & 0.88 & 0.9 & 0.89 & 0.92 & 0.93 & 0.9 \\
\hline Theft & 1.72 & 1.67 & 1.53 & 1.29 & 1.22 & 1.49 \\
\hline Larceny & 0.78 & 0.78 & 0.76 & 0.79 & 0.76 & 0.78 \\
\hline Rape total & 5.48 & 5.79 & 5.84 & 5.6 & 5.02 & 5.55 \\
\hline Rape by force & 5.48 & 5.74 & 5.83 & 5.59 & 5.21 & 5.57 \\
\hline
\end{tabular}

Table 2: Unfounded crimes as percentage of all crimes in each category, nationwide in the USA.

\section{Statistical Analyses}

We first performed a Kruskal Wallis Non Parametric Chi Square test of Goodness-of-fit on the proportions of false and baseless allegations of rape to test whether the proportions were equal for 2006-2010 and 1992. If the new guidelines of the FBI were followed by law enforcement agencies in the U.S., then a significant drop in the proportion of false and baseless allegations of rape was to be expected. 
We performed a Kruskal Wallis Non Parametric Chi Square test of Goodness-of-fit on the proportions of false and baseless allegations to test whether the proportions were equal for all offence types. If a significant result was obtained a post hoc test was performed to see which proportion of false and baseless allegations differed significantly with the other proportions. A Non Parametric Chi Square test was performed with an expected value of $98.84 \%$ true allegations, and $1.16 \%$ false and baseless allegations, since the overall average proportion of false and baseless allegations for all offence types and all years combined was $1.16 \%$ (Table 2).

\section{Results}

False and baseless allegations of rape were not equally distributed for the period 2006-2010 as compared to the figures of $1992, X^{2}(1$, $\mathrm{N}=2000)=4.54, \mathrm{p}=0.033$. False and baseless allegations were not equally distributed across offence types $\mathrm{X}^{2}(7, \mathrm{~N}=8000)=120.19, \mathrm{p}<0.0001$. The post hoc test revealed significant differences with the average of $1.16 \%$, $\mathrm{SD}=0.04$ for false and baseless allegations of murder $\mathrm{M}=3.30, \mathrm{SD}=0.20$, $\mathrm{X}^{2}(1, \mathrm{~N}=1000)=39.94, \mathrm{p}<0.0001$, false and baseless allegations of rape $\mathrm{M}=5.55, \mathrm{SD}=0.29, \mathrm{X}^{2}(1, \mathrm{~N}=1000)=171.94, \mathrm{p}<0.0001$, and false and baseless allegations of robbery $\mathrm{M}=5.78, \quad \mathrm{SD}=0.27, \quad \mathrm{X}^{2} \quad(1$, $\mathrm{N}=1000)=187.78, \mathrm{p}<0.0001$. There were no differences between the average of $1.16 \%$ for all allegations combined, and false and baseless allegations of assault $\mathrm{M}=0.95, \mathrm{SD}=0.05, \mathrm{X}^{2}(1, \mathrm{~N}=1000)=0.22, \mathrm{p}=0.64$, of larceny $\mathrm{M}=0.78, \mathrm{SD}=0.01, \mathrm{X}^{2}(1, \mathrm{~N}=1000)=0.22, \mathrm{p}=0.64$, of theft $\mathrm{M}=1.49, \mathrm{SD}=0.20, \mathrm{X}^{2}(1, \mathrm{~N}=1000)=0.59, \mathrm{p}=0.44$, of burglary $\mathrm{M}=0.90$, $\mathrm{SD}=0.05, \mathrm{X} 2(1, \mathrm{~N}=1000)=0.59, \mathrm{p}=0.44$, and of manslaughter $\mathrm{M}=1.35$, $\mathrm{SD}=0.96, \mathrm{X}^{2}(1, \mathrm{~N}=1000)=1.01, \mathrm{p}=0.32$.

In the years 2006-2010 all law enforcement agencies combined reported to the UCR of the FBI that yearly between 4,400 and 5,100 allegations of rape were false and baseless allegations, while 82,000 to 85,000 that are considered to be true allegations (Table 1) [20]. False and baseless allegations of rape constitute about $5 \%$ of all rape allegations; it is at least five times the proportion of some other crimes. For instance, unfounded theft, assault, and fraud allegations constitute approximately $1 \%$ of all allegations of theft, assault or fraud. The only other crime type with comparable rates of false and baseless allegations was robbery (Table 2) [20].

\section{Discussion}

\section{General discussion}

The new guidelines issued by the FBI seem to have been implemented by law enforcement agencies in the USA significant drop in the proportion of false and baseless allegations of rape was observed since the new guidelines were issued. Since the new guidelines are more stringent, a drop was to be expected when these guidelines were followed. Under the new guidelines law enforcement agencies can no longer use the label as a dustbin for unwanted allegations of rape or to clear crimes. There was some preliminary evidence that the guidelines were already followed by one of the largest police departments in the U.S., the LAPD [19]. Based on the current results it seems that we can extend this assertian to all law enforcement agencies in the U.S. that contributed to the UCR data. Our 5\% figure is also consistent with findings of other researchers in the field of allegations of rape. Ferguson and Malouff [21] found a rate of 5\% confirmed false allegations in their meta-analysis on seven studies on the prevalence of false allegations.
False allegations of rape are a problem for all parties involved. In cases where no one is accused directly, no innocent suspects are targeted; false allegations still result in a waste of police resources. The prevalence of false allegations of rape is at the kernel of a heated debate among researchers [3]. Methodological problems jeopardized the validity of the reported prevalence figures [4]. The current estimate on the prevalence of false allegations of rape is probably a conservative estimate. It is so because the UCR Program of the FBI revised the criteria, and since 1994 uses more stringent criteria than before. Now it has to be established through investigation that no crime had occurred before an allegation of a crime can be categorized as unfounded. It is difficult to establish that a crime did not occur, especially in the context of rape.

A rape scenario as well as a consensual sex scenario usually only involves two parties. If one of the parties is lying about the true nature of the scenario it may be difficult to proof that the crime either occurred or did not occur. If, for instance, the sexual encounter is not disputed, but only the consensual nature, then other evidence should discriminate between rape and a consensual scenario. If such evidence is absent then it is impossible to discriminate between rape and a consensual scenario. In that case, doubt concerning the true nature of the allegation will always persist. A false complainant who never retracts her story of rape, and the investigation does not reveal proof of its falsity or baselessness, such a case will never be classified as an unfounded rape allegation following the current criteria of the FBI.

The results of the current study, therefore, seem to indicate that the new guidelines of the FBI are followed by most or all law enforcement agencies in the U.S. As a consequence of the new guidelines, law enforcement agencies do not seem to, routinely, use the unfound category to clear criminal cases anymore. Therefore, a drop in the number of false and baseless allegations of rape was to be expected when the new policy was effective.

\section{The variation of prevalence rates}

Prevalence rates of false and baseless allegations vary across offence types. The prevalence rate of false and baseless allegations of rape is higher than the prevalence rate of most other offence types. In most offences where insurances could cover the damage of the offence, such as theft, prevalence rates of false and baseless allegations are more than five times smaller than the prevalence rates of false and baseless allegations of rape. The only comparable prevalence rate of false and baseless allegations is the prevalence of false and baseless allegations of burglary. One explanation might be that some false allegations were caused by insurance fraud.

False and baseless allegations of murder are also higher than false and baseless allegations of most other offence types. But, it is still almost halve of the prevalence of false and baseless allegations of rape or burglary. A high prevalence rate of false and baseless allegations of murder may seem surprising at first, especially for those who are unfamiliar with the legal system of the United States. The high prevalence rate of murder is explained by the diversity of false and baseless allegations of murder. An evident false allegation of murder is an allegation of murder on for instance a neighbor, and police investigation reveals that the neighbor is still alive. Another, far more frequent, false or baseless allegation of murder is the allegation in which the police investigation revealed that the killing was justified by law in the United States. One example is killing in self-defence, but another example might be the killing of a burglar in your home; a sometimes justified act in the United States [20]. But, also cases in 
which police officers kill someone in the line of duty are first classified as allegations of murder until the police investigation reveals that the killing was justified [20].

\section{Limitations}

The most important limitation of the current study is the process of data gathering. Since we did not gather data ourselves we cannot ascertain the process of data gathering. We cannot check, for instance, how strict the guidelines were followed by all the different agencies in the United States. Nor can we exclude any mistakes made by the police officers who entered or delivered data. The motivation of the police agencies to report valid and reliable figures was also not under our control. Finally, another important limitation of the current study is that not all agencies in the USA contribute to the UCR which could compromise our results, and could damage the generalisability of our results.

\section{Conclusion}

We reported recent figures on the prevalence of false and baseless allegations. Based on the current findings, we can conclude that at least $1 \%$ of all allegations are false or baseless. The most prominent types of false and baseless allegations are false and baseless allegations of burglary, and false and baseless allegations of rape. False or baseless allegations of burglary result in a waste of valuable police resources, and could lead to unjustified insurance expenses which could lead to higher insurance policies for honest people. False allegations of rape, however, are more harmful. Besides wasting police time, they cause public unrest, and innocents could be convicted or suspected of a rape they did not commit. It seems imperative to differentiate false from true allegations of rape at an early stage of the police investigation. A practical tool to do so might therefore be at place. To date, an objective, reliable, and valid measurement tool, however, is lacking, and should be the focus of future studies. Based on the results of the current study, the statement by Spohn et al. [19] that "One conclusion that can be drawn from these data is that the LAPD is clearing sexual assault cases as unfounded appropriately most, but not all, of the time" (p: 173) could maybe be generalized to the U.S. as a whole. Thus, it seems warranted to conclude that the new guidelines are followed not only by the LAPD, but by almost all law enforcement agencies in the US.

\section{References}

1. Brownmiller S (1975) Against our will: Men, women and rape. NY: Simon and Schuster.
2. Kanin EJ (1994) False rape allegations. Arch Sex Behav 23: 81-92.

3. Greer E (1999) The truth behind legal dominance feminism's 'two percent false rape claim' figure 33. Loy L A L Rev 3: 947-972.

4. Rumney PNS (2006) False allegations of rape. Cambridge Law Journal 6: 128-158.

5. Katz S, Mazur MA (1979) Understanding the rape victim: A synthesis of research findings. Wiley, NY, USA.

6. Hursch CJ, Selkin J (1974) Rape prevention research project. Division of Psychiatric Hospitals, Department of Health and Service, Denver, Colorado.

7. Rumney PNS, Taylor MM (2002) The use of syndrome evidence in rape trials. Criminal Law Forum 1: 471-506.

8. Belknap J (2010) Rape: too hard to report and too easy to discredit victims. Violence against Women 16: 1335-1344.

9. Lisak D, Gardinier L, Nicksa SC, Cote AM (2010) False allegations of sexual assualt: an analysis of ten years of reported cases. Violence against women 16: 1318-1334.

10. Saunders CL (2012) The truth, the half-truth, and nothing like the truth: Reconceptualizing false allegations of rape. Br J Criminol 52: 1152-1171.

11. Her Majesty's Inspectorate of Constabulary (HMIC), Her Majesty's Crown Prosecution Service Inspectorate (HMCPSI) (2002) A report on the joint inspection into the investigation and prosecution of cases involving allegations of rape. London pp: 1-99.

12. Jordan J (2004) Beyond belief? Police, rape and women's credibility. Criminol Crim Justice 4: 29-59.

13. Kelly L, Lovett J, Regan L (2005) A gap or a chasm? Attrition in reported rape cases. London: Home Office Research, Development and Statistics Directorate.

14. Lea SJ, Lanvers U, Shaw S (2003) Attrition in rape cases: Developing a profile and identifying relevant factors. Br J Criminol 43: 583-599.

15. Dershowitz AM (1994) False reports of rape. London, UK: Little, Brown and Company.

16. Gregory J, Lees S (1996) Attrition in rape and sexual assault cases. Br J Criminol 36: 1-17.

17. Federal Bureau of Investigation (2010) A word about UCR data. Uniform Crime Reports. Federal Bureau of Investigation Criminal Justice Information Services Division Crime Statistics Management Unit.

18. Uniform Crime Reporting (2004) Uniform Crime Reporting handbook. Washington, D. C.: Uniform Crime Reporting Program.

19. Spohn CC, White C, Tellis KM (2014) Unfounding sexual assault: Examining the decision to unfound and identifying false reports. Law Soc Rev 48: 161-192.

20. Federal Bureau of Investigation (2012) Uniform Crime Reporting (UCR) Program's master files.

21. Ferguson CE, Malouff JM (2016) Assessing police classifications of sexual assault reports: A meta-analysis of false reporting rates. Arch Sex Behav 4: 1185-1193. 